\title{
Child Care Subsidies Critical for Low-Income Families Amid Rising Child Care Expenses
}

KRISTIN SMITH AND NICHOLAS ADAMS

$\mathrm{P}$ resident Obama in his 2013 State of the Union address called for making "high-quality preschool available to every child in America" and laid out a plan to invest in young children and support low-income working families. ${ }^{1}$ This plan proposed a joint federal-state partnership to provide high-quality public preschool for all four-year-old children from low-income families (which include poor families), as well as an increase in investments in Head Start programs and an expansion of early care and education programs for infants and toddlers. ${ }^{2}$ The President's budget includes increased funding in fiscal year 2014 to expand and improve infant and toddler care and to increase child care subsidies to help low-income families pay for child care. In addition, the U.S. Department of Health and Human Services recently proposed new regulations to ensure children's health and safety and improve the quality of child care among child care providers who accept child care subsidies for low-income families through Child Care and Development Fund (CCDF) funds. ${ }^{3}$

The high cost of child care is a barrier to employment among low-income families (those living at or below 200 percent of poverty) with young children. ${ }^{4}$ Child care subsidies are designed to support both parental employment and child development by lowering the cost of child care and making high-quality child care affordable to low-income families. High-quality child care promotes child development, as it provides children the opportunity to learn and develop the skills necessary to succeed in school and in life. ${ }^{5}$ Several studies have shown that low-income families who receive child care subsidies experience higher rates of employment than similar families who do not receive subsidies. ${ }^{6}$ Recipients of child care subsidies also experience fewer child care-related work disruptions, making it easier for them to maintain employment, and underscoring the value of child care subsidies. ${ }^{7}$

In the wake of the Great Recession and subsequent slow job growth and recovery, employment support for low-income families is increasingly important as families struggle to obtain and maintain work. Child care is particularly salient for rural families with young children because
Key Findings
- Average monthly child care expenditures increased by 26 percent from 2005 to 2011 among families with employed mothers and children under the age of 6 . This increase was evident in metro (or urban) but not nonmetro (or rural) places.
- Across place, low-income families (those living at or below 200 percent of poverty) with children paid a larger percentage of family income on child care. For example, nonmetro low-income families paid 18 percent of their family incomes on child care, whereas nonmetro families with higher incomes paid only 8 percent.
- Employed, poor mothers with child care expenses spent more than one-third of their incomes on child care in 2005 and 2011.
- Low-income families receiving child care subsidies had lower child care expenditures in 2005 and 2011 than did similar families who did not receive child care subsidies.

single and married rural mothers with children under age 6 are more likely to be employed than their urban counterparts ${ }^{8}$ and because rural families generally have fewer available child care options. ${ }^{9}$

Yet, funding for many programs is facing cuts or reductions as Congress deliberates deficit reduction and raising the debt ceiling, and the effects of sequestration are being felt. States are also trying to balance their budgets, with some viewing cuts in services for families as a necessary step in this process. ${ }^{10}$ Although some states are beginning to recover from the Great Recession and are increasing or 
restoring spending on child care assistance programs, many are still experiencing economic fallout and reduced budgets, including funding to child care programs. ${ }^{11}$ In 2012, twenty-three states reported having waiting lists to receive child care assistance, up from twenty states in $2005 .{ }^{12}$ Some states have increased family copayments for child care, and others have reduced the length of time parents are eligible to receive assistance while searching for a job. ${ }^{13}$

This policy brief compares the shares of income spent on child care in 2005 and 2011 among families with children under the age of 6 in which the mother was employed and had child care expenses. ${ }^{14}$ Data were collected by the U.S. Census Bureau in the spring of 2005 on the 2004 Survey of Income and Program Participation (SIPP) Wave 4 Child Care Topical Module and in the spring of 2011 on the 2008 SIPP Wave 8 Child Care Topical Module. We make comparisons between nonmetropolitan (or rural) and metropolitan (or urban) residents. Our measure of place is based on the U.S. Census Bureau measure, which classifies individuals based on their county of residence. Metropolitan areas consist of core counties with one or more cities of 50,000 or more residents plus surrounding counties that are economically tied to the core county through commuting patterns.

The results reveal that child care expenditures (in constant 2011 dollars) were higher on average in 2011 than in 2005 and that low-income families who received child care subsidies paid less for child care in 2005 and 2011 than lowincome families who did not receive child care subsidies. Although it is beyond the scope of this brief to identify the reasons for the increase in child care expenditures, it is possible that the composition of families with child care expenditures changed from 2005 to 2011. In hard economic times, low-income families, who typically pay less for child care, may look for ways to reduce their child care expenses. They may rearrange work schedules so parents can share child care responsibilities, or they may seek help from relatives. Because this analysis includes only those families with child care expenditures, it may be that families who paid for child care in 2011 were those with higher incomes, who typically spent more on child care overall.

\section{Child Care Expenses Rose from 2005 to 2011}

Average monthly child care expenditures increased by 26 percent over six years among families with an employed mother and children under the age of 6, from \$548 in 2005 to $\$ 690$ in 2011 (in constant 2011 dollars; see Table 1). ${ }^{15}$ This increase in child care expenditures translated into an increase in the percentage of family income spent on child care, from 8 percent in 2005 to 10 percent in 2011.
TABLE 1. MONTHLY CHILD CARE COSTS, FAMILY INCOME, AND PERCENTAGE OF FAMILY INCOME SPENT ON CHILD CARE FOR FAMILIES WITH AN EMPLOYED MOTHER, SPRING 2005 AND SPRING 2011

\begin{tabular}{l|cc|cc|cc}
\hline \multicolumn{1}{c}{$\begin{array}{c}\text { Average monthly } \\
\text { child care costs }\end{array}$} & \multicolumn{2}{c}{$\begin{array}{c}\text { Average monthly } \\
\text { family income }\end{array}$} & \multicolumn{2}{c}{$\begin{array}{c}\text { Percentage of family } \\
\text { income spent on } \\
\text { child care }\end{array}$} \\
\hline \multirow{4}{*}{ Total } & 2005 & 2011 & 2005 & 2011 & 2005 & 2011 \\
\cline { 2 - 7 } Nonmetro & $\$ 548$ & $\$ 690^{*}$ & $\$ 7,083$ & $\$ 7,708^{*}$ & 8 & $10^{*}$ \\
Metro & $\$ 435$ & $\$ 458$ & $\$ 5,494$ & $\$ 5,400$ & 9 & 9 \\
\hline
\end{tabular}

Source: 2004 SIPP, Wave 4 and 2008 SIPP, Wave 8

Note: Asterisks signify statistically significant difference from 2005 to $2011(p<0.05)$. 2005 values are in constant 2011 dollars.

This increase was observed only in metropolitan (metro) areas; the amount spent by nonmetropolitan (nonmetro) families on child care was not statistically different in 2005 than in 2011. Child care expenditures and family incomes were both lower among nonmetro families than metro families in both years, resulting in a similar proportion of total family income spent on child care across place by 2011 .

In 2005, child care expenditures among low-income families who made payments for child care were similar in nonmetro and metro areas (see Figure 1). Due to large increases in the amount spent on child care among lowincome metro families from 2005 to 2011, by 2011 lowincome metro families had higher child care expenditures than their nonmetro counterparts.

Figure 1. AVERAge MONTHLY CHILd CARE EXPENSES FOR LOW-INCOME FAMILIES, 2005 AND 2011

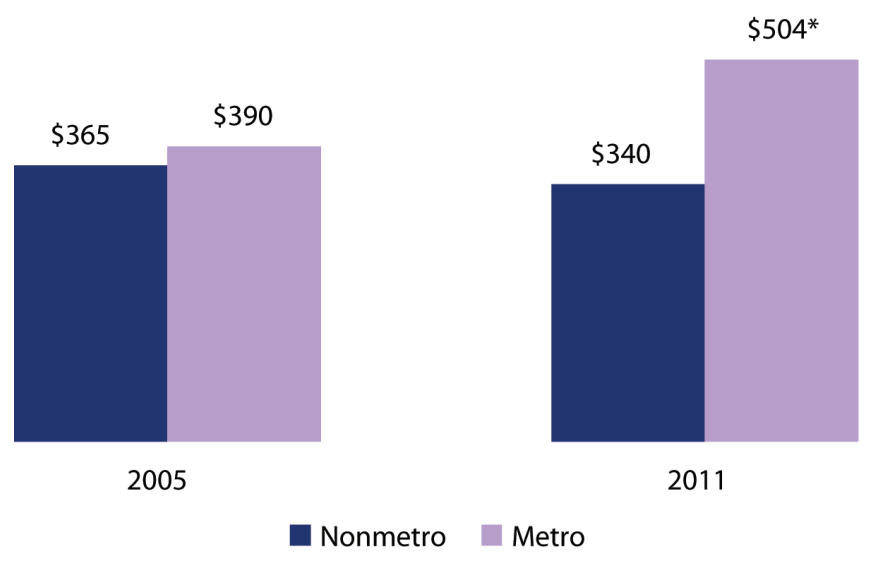

Source: 2004 SIPP, Wave 4 and 2008 SIPP, Wave 8

Note: Asterisks signify statistically significant difference from 2005 to $2011(p<0.05)$. 2005 values are in constant 2011 dollars. 
Poor and Low-Income Families Shoulder Larger Child Care Expense Burden

Child care expenditures represent a heavy burden for families with fewer economic resources. For example, in 2011, poor families with young children spent 34 percent of monthly income on child care expenses, just under four times the share spent by families living above 200 percent of poverty (see Figure 2). Likewise, families with young children living at 100 to 199 percent of poverty devoted 20 percent of monthly income to child care expenses, more than twice the share spent by families living above 200 percent of poverty.

Figure 2. Percentage of Monthly FAmily income SPENT ON CHILD CARE, BY MOTHER'S POVERTY STATUS, SPRING 2005 AND SPRING 2011

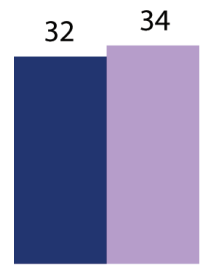

In poverty

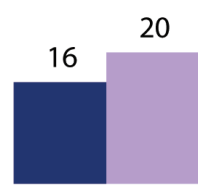

$100 \%$ to $199 \%$ of poverty

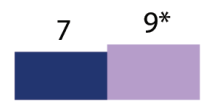

At or above $200 \%$ of poverty

Source: 2004 SIPP, Wave 4 and 2008 SIPP, Wave 8 Note: Asterisks signify statistically significant difference from 2005 to $2011(p<0.05)$.

The pattern of a greater child care expense burden experienced by poorer families is evident among those living in both nonmetro and metro America in 2005 and 2011. Nonmetro and metro low-income families spent substantially larger percentages of monthly income on child care expenses than families with greater economic resources (see Table 2).

The percentage of monthly income spent on child care expenses increased from 2005 to 2011 for families across the three monthly income levels shown in Table 2. Families earning less than $\$ 2,999$ per month spent 26 percent of their monthly incomes on child care in 2011, compared with 20 percent in 2005. In contrast, families earning $\$ 4,500$ or more per month spent 8 percent of their monthly incomes on child care costs in 2011, up from 7 percent in 2005 .

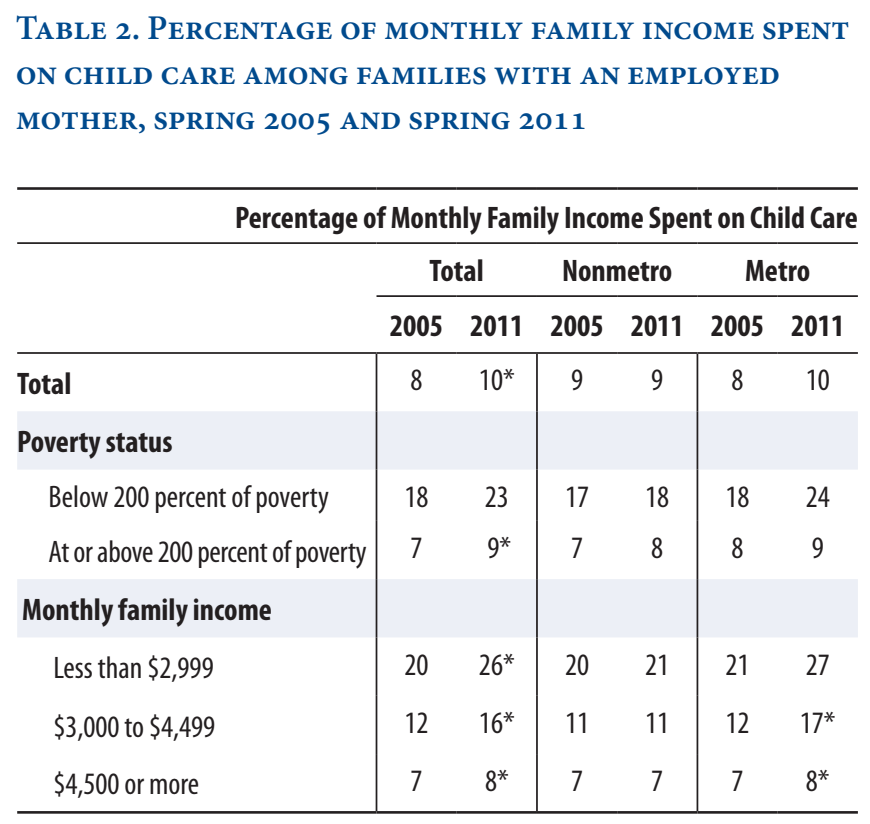

Source: 2004 SIPP, Wave 4 and 2008 SIPP, Wave 8

Note: Asterisks signify statistically significant difference from 2005 to $2011(p<0.05)$.

\section{Child Care Subsidies Ease Expense Burden}

Because child care subsidies can reduce child care expenses to very low amounts or even zero, this next set of analyses examines low-income families with children under the age of 6 who attended organized child care, regardless of whether or not child care incurred a cost. ${ }^{16}$ Child care subsidies ${ }^{17}$ are associated with lower average child care expenditures. In both 2005 and 2011, lowincome families with children under the age of 6 who received child care subsidies had lower child care expenditures than similar families who did not receive child care subsidies (see Figure 3), despite similar work hours among the two groups (both worked an average of 23 hours per week in 2011). In addition, low-income families receiving child care subsidies had lower monthly family incomes than their counterparts who did not receive subsidies, but each spent similar proportions of monthly income on child care (data not shown). 
Figure 3. AVERAge MONTHLY CHILD CARE EXPENSES AMONG LOW-INCOME FAMILIES, BY SUBSIDY RECEIPT, 2005 AND 2011

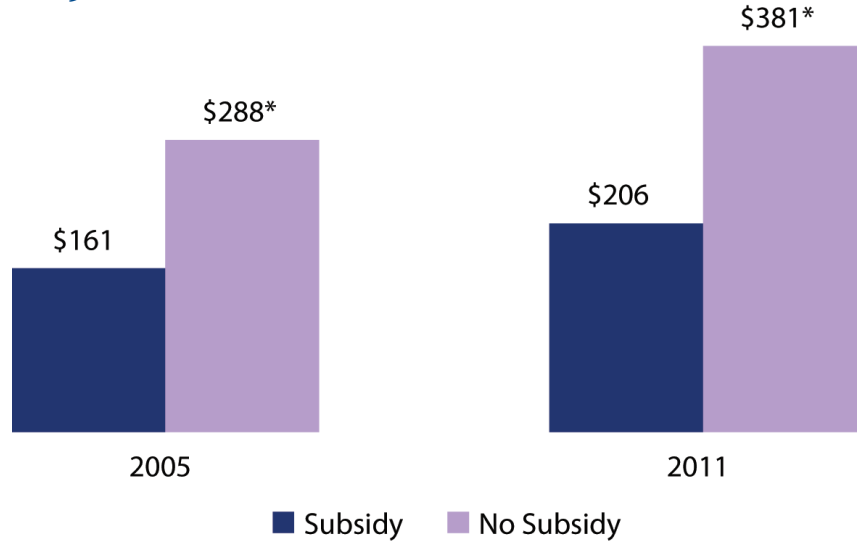

Source: 2004 SIPP, Wave 4 and 2008 SIPP, Wave 8

Note: Asterisks signify statistically significant difference between subsidy and no subsidy receipt $(p<0.05) .2005$ values are in constant 2011 dollars.

\section{Policy Implications}

Since 2005, average child care expenditures among families who paid for child care increased significantly, especially among metro families. Although average child care expenses have increased and the number of children eligible for and requiring child care assistance has increased significantly, the number of families receiving child care assistance has decreased, ${ }^{18}$ as has inflationadjusted funding for the Child Care and Development Block Grant (CCDBG). ${ }^{19}$ While some low-income families experienced some relief in 2010 from the American Recovery and Reinvestment Act (ARRA), which infused extra funding for child care subsidies, many states have since run out of these extra funds.

The Obama administration and Congress are seeking ways to reduce government spending, yet it should be noted that a gap already exists between the number of children eligible for child care assistance and the number served. In 2009, only 18 percent of children eligible for federal child care assistance actually received it. ${ }^{20}$ This percentage is likely even lower today, because the number of children receiving assistance has decreased as the number of low-income children has grown in recent years.

The high cost of child care can be a barrier to seeking or maintaining employment among poor and low-income families. Child care assistance can help low-income families find and maintain employment ${ }^{21}$ which is especially important as families attempt to rebuild after the Great Recession. In 2011, families in poverty spent one-third of their incomes on child care, and families at 100 to 199 percent of poverty spent 20 percent of their incomes on child care, a much higher proportion than families with greater economic resources, who spent 9 percent.

Both nonmetro and metro families benefit from child care assistance. Child care represents a considerable expense for poor and low-income working families in America, regardless of location. Many low-income families depend on child care subsidies to maintain employment, but affordable, high-quality child care is also important for the well-being of our children. Because many working families struggle to make ends meet, child care assistance not only helps families pay the bills but also provides an opportunity for child development for their children.

With the looming threat of funding cuts, high child care expenses can become an even greater burden and affect more families. Maintaining funding for the CCDBG should be a strong focus of state and federal policy.

\section{Data}

This brief uses data from the Survey of Income and Program Participation (SIPP) collected in the spring of 2005 and the spring of 2011 by the U.S. Census Bureau. Following U.S. Census Bureau methodology, the percentage of monthly family income spent on child care is calculated as the ratio of average monthly child care expenditures (prorated from weekly averages) to average family monthly income. Low-income families include those living at or below 200 percent of the federal poverty level. Comparisons presented in the text are statistically significant $(\mathrm{p}<0.05)$. We use the U.S. Census Bureau measure of nonmetro residence. Individuals are classified as metro and nonmetro based on their county of residence. Metro areas consist of core counties with one or more cities of 50,000 or more residents plus surrounding counties that are economically tied to the core county through commuting patterns. 
E N D N O T E S

1. President Barack Obama, "State of the Union," February 12,2013

2. The White House, “Fact Sheet: President Obama's Plan for Early Education for all Americans" (Washington, DC: Office of the Press Secretary, February 13, 2013).

3. For more information, refer to Department of Health and Human Services, "Proposed Rules. Child Care and Development Fund (CCDF) Program," Federal Register, 78, No. 97 (2013), available at http://www.gpo.gov/fdsys/pkg/FR-201305-20/pdf/2013-11673.pdf.

4. Charles L. Baum, "A Dynamic Analysis of the Effect of Child Care Costs on the Work Decisions of Low-Income Mothers with Infants," Humanities, Social Sciences and Law, vol. 39, no. 1 (2002): 139-164.

5. Eric Dearing, Kathleen McCartney, and Beck A. Taylor, "Does Higher Quality Early Child Care Promote Low-Income Children's Math and Reading Achievement in Middle Childhood?", Child Development, vol. 80, no. 5 (2009): 1329-1349; National Research Council and the Institute of Medicine, From Neurons to Neighborhoods: The Science of Early Childhood Development (Washington, DC: National Academy Press, 2000).

6. Jay Bainbridge, Marcia K. Meyers, and Jane Waldfogel, "Child Care Policy Reform and the Employment of Single Mothers," Social Science Quarterly, vol. 84, no. 4 (2003): 771-791; Fred Brooks et al., "Impacts of Child Care Subsidies on Family and Child Well-Being," Early Childhood Research Quarterly, vol. 17, no. 4 (2002): 498-511; Erdal Tekin, "Child Care Subsidy Receipt, Employment, and Child Care Choices of Single Mothers," Economic Letters, vol. 89, no. 1 (2005): 1-6.

7. Nicole Forry and Sandra Hofferth, "Maintaining Work: The Influence of Child Care Subsidies on Child Care-Related Work Disruptions," Journal of Family Issues, vol. 32, no. 3 (2011): 346-368; Julie Press, Jay Fagan, and Lynda Laughlin, "Taking Pressure Off Families: Child-Care Subsidies Lessen Mother's Work-Hour Problems," Journal of Marriage and Family, vol. 68, no. 1 (2006): 155-171.

8. Kristin Smith, Working Hard for the Money: Trends in Women's Employment 1970-2007, A Carsey Institute Report on Rural America (Durham, NH: Carsey Institute, University of New Hampshire, 2008).

9. Rachel Gordon and Lindsay Chase-Lansdale, "Availability of Child Care in the United States: A Description and Analysis of Data Sources," Demography, vol. 38 (2001): 299-316.

10. Karen Schulman and Helen Blank, "State Child Care Assistance Policies 2011: Reduced Support for Families in Challenging Times" (Washington, DC: National Women's Law Center, October 2011).
11. Karen Schulman and Helen Blank, "Downward Slide: State Child Care Assistance Policies 2012” (Washington, DC: National Women's Law Center, October 2013).

12. Karen Schulman and Helen Blank, "State Child Care Assistance Policies 2006: Gaps Remain, with New Challenges Ahead" (Washington, DC: National Women's Law Center, September 2006).

\section{Schulman and Blank, "Downward Slide."}

14. We focus our analysis on children under the age of 6 because of the greater use of child care and child care subsidies for this age group. However, low-income children under the age of 12 are also eligible to receive child care subsidy assistance.

15. This rise in child care costs is also documented using SIPP data from 1985 to 2011. See Lynda Laughlin, "Who's Minding the Kids? Child Care Arrangements: Spring 2011," Current Population Reports, P70-135 (Washington, DC: U.S. Census Bureau, 2013), available at http://www.census.gov/ prod/2013pubs/p70-135.pdf.

16. In this analysis, "organized child care" includes day care centers, nursery schools, Head Start programs, or family day care.

17. The child care subsidy variable is based on the following question in the SIPP: "Did any government agency help pay for this arrangement for the YOUNGEST child?" This question is then asked for each child for all arrangements used.

18. Administration for Children and Families, "FFY 2005 CCDF Data Tables: Table 1. Child Care and Development Fund Preliminary Estimates Average Monthly Adjusted Number of Families and Children Served (FFY 2005)" (Washington, DC: U.S. Department of Health and Human Services, June 20, 2006); Administration for Children and Families, "FFY 2010 CCDF Data Tables: Table 1. Child Care and Development Fund Preliminary Estimates Average Monthly Adjusted Number of Families and Children Served (FFY 2010)" (Washington, DC: U.S. Department of Health and Human Services, December 23, 2011).

19. Administration for Children and Families, "Fiscal Year 2006: Justification of Estimates for Appropriations Committees" (Washington, DC: U.S. Department of Health and Human Services, 2006); Administration for Children and Families, "Fiscal Year 2013: Justification of Estimates for Appropriations Committees" (Washington, DC: U.S. Department of Health and Human Services, 2013).

20. ASPE Staff, "Estimates of Child Care Eligibility and Receipt for Fiscal Year 2009” (Washington, DC: U.S. Department of Health and Human Services, 2012), available at http://aspe.hhs.gov/hsp/12/childcareeligibility/ib.cfm.

21. Press, Fagan, and Laughlin, “Taking Pressure Off Families.” 


\section{ABOUT THE AUTHORS}

Kristin Smith is a family demographer at the Carsey Institute and research assistant professor of sociology at the University of New Hampshire (kristin.smith@unh.edu).

Nicholas Adams is a research assistant at the Carsey Institute and a doctoral student in sociology at the University of New Hampshire (nau56@wildcats.unh.edu).

\section{A C K N O W L E D G M E N T S}

The authors thank Lynda Laughlin at the U.S. Census Bureau; Karen Schulman at the National Women's Law Center; Bruce Mallory, Marybeth Mattingly, Curt Grimm, Amy Sterndale, and Laurel Lloyd at the Carsey Institute; and Barbara Ray at Hiredpen for their thoughtful comments and suggestions.

\section{A UNIVERSITY Aiv of NEW HAMPSHIRE}

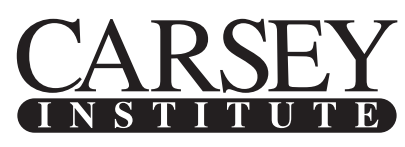

Building knowledge for families and communities

The Carsey Institute conducts policy research on vulnerable children, youth, and families and on sustainable community development. We give policy makers and practitioners timely, independent resources to effect change in their communities.

This work was supported by the Annie E. Casey Foundation, the W. K. Kellogg Foundation, and anonymous donors.

Huddleston Hall

73 Main Street

Durham, NH 03824

(603) $862-2821$

www.carseyinstitute.unh.edu 